\title{
GROUP LIFE INSURANCE: ITS LEGAL ASPECTS
}

\author{
FranK W. HANFT*
}

\section{Nature and History}

Definitions of group insurance are usually nothing more than summaries of the common attributes of this device. If one or more of the attributes usually present and included in the definitions were missing, still the device would be group insurance, just as a man with only one leg is still a man. Which of the usual attributes of group insurance are essential characteristics may be a matter of opinion; but it is suggested that any form of insurance which by a single policy gives insurance to individuals belonging to a definite group already in existence is group insurance. By far the most common type of group on which this form of insurance is in fact written is the group formed by the employees of a single employer. It is this fact which makes group insurance an important agency for the welfare of wage earners.

Group insurance as above identified appeared in litigation as early as I892. In the case of Enright $v$. Standard Life \& Accident Insurance Company ${ }^{2}$ was involved an accident policy issued by the insurance company to a railroad, covering such of

* LL.B., I924, LL.M., I929, A.B., I929, University of Minnesota; S. J. D., I93I, Harvard University. General law practice, I924-1929. Instructor in Law, University of Minnesota, 1929-I930; Fairchild Research Fellow, Harvard Law School, 1930-r931; Associate Professor of Law, University of North Carolina, I93I-; Associate Utilities Commissioner, North Carolina, 1934. Author of Control of Public Utilities in Minnesota (1932) 16 Minnesota Law Review, 457 (1932); Control of Electric Rates in North Carolina (1934) 12 North Carolina Law Review, 289; and other articles and comments.

Much of the thought of this article is the result of suggestions from Professor M. Breckenridge of the faculty of the Law School of the University of North Carolina. Footnote 19 and the text relating thereto was contributed by him.

${ }^{1}$ The National Convention of Insurance Commissioners in 1918 adopted a definition of group insurance now recognized by insurance companies and embodied in several state statutes. According to this definition, "group life insurance is that form of life insurance covering not less than fifty employecs with or without medical examination written under a policy issued to the employer, the premium on which is to be paid by the employer or by the employer and employees jointly, and insuring only all of his employees or all of any class or classes thereof determined by conditions pertaining to the employment, for amounts of insurance based upon some plan which will preclude individual selection, for the benefit of persons other than the employer; provided, however, that when the premium is to be paid by the employer and employees jointly and the benefits of the policy are offered to all eligible cmployees, not less than seventy-five per cent of such employees may be so insured." NAT. IndustrinL Conp. Bonnd, Industrial Group Insurance (1927), I, 2, n. I. The language is repeated in N. C. Code ANn (Michic, I931) $\$ 6466 \mathrm{a} ; \mathrm{N}$. Y. Cons. Laws (Cahill 1930) c. 30, \$rora ( $\mathrm{I}$ ). For a comparison betwcen group insurance and workmen's compensation insurance, see Leach v. Met. I. I. Co., 124 Kan. 584, 261 Pac. 603 (I927).

${ }^{2} 91$ Mich. 238,51 N. W. 928 (1892). 
the railroad's employees as should be entered on the schedule of employees insured. The employees paid the premiums. In this particular the policy differed from the usual group policies of today, the premiums of which are paid in whole or in part by the employer. Apparently the insurance was compulsory. Certificates were issued to the individual employees, and each certificate provided that if the employee holder left the service of the employer, his insurance ended immediately. Thus this insurance covered by a single master policy issued to a railroad the individuals belonging to a group, namely the employees of the railroad, and covered the individuals only so long as they belonged to the group. A similar policy was passed upon in Carpenter $v$. Chicago \& Eastern Illinois Railroad Company in 1898 . The facts in Fidelity \& Casualty Company v. Ballard \& Ballard Co., ${ }^{4}$ decided in I899, were that an employer applied to an agent of an insurance company for a "Workman's Collective Policy," to be issued to the employer for the benefit of the employees, by which policy the insurance company was to undertake to pay one year's wages in case of death and certain weekly payments for injuries. The agent agreed that the insurance would be in force until notice of rejection if the policy were rejected. It was, but the oral contract of insurance existing meanwhile was held valid.

The essential characteristics of group insurance, then, had been developed before the close of the last century. However, the spectacular growth of group life insurance did not begin until rgr2. In that year a single employer covered its 3000 employees for about $\$ 6,000,000$. At the close of the year there was in effect about thirteen million dollars of group life insurance; by the end of 1915 this had leaped to one hundred millions; this figure had increased ten fold in four years; and by the end of 1926 the figure had swelled to about fifty-five hundred millions of insurance on about four million seven hundred thousand employees. ${ }^{5}$ The depression arrested this phenomenal growth, ${ }^{6}$ but the present industrial revival has stimulated a new expansion. ${ }^{7}$ The size already gained by this relatively new form of insurance makes it an important agency for social welfare; its growth, striking even during an era when unprecedented growth was usual and expected, makes it doubly important.

\section{Its Place in Insurance Law}

Perhaps it is unfortunate that the new device bears the name "group insurance," because the name calls attention to the fact that the scheme is, in truth, a form of insurance. There already exists a large mass of law governing insurance and waiting

${ }^{3} 21$ Ind. App. 88, 51 N. E. 493 (1898).

105 Ky. 253, 48 S. W. 1074 (1899).

- Nat. Industrial Conf. Board, op. cit. supra note $\mathbf{I}$, at 9.

'In North Carolina, according to the records in the office of the Insurance Commissioner, the amount of group life insurance in force declined along with ofiner forms of life insurance. Dec. 3I, I93I there was $\$ 85,597,764$ of group life insurance in effect in the state; by Dec. $3 x, 1933$ the figure had dwindled to $\$ 73,216,714$.

${ }^{3}$ The new group life insurance written by forty-two companies during the first nine months of 1934 amounted to $\$ 36 \mathrm{r}, 301,000$, a gain of $54.3 \%$ over the first nine months of r933. I3I WEEKLY UNDERWRITER 763 (Oct. 20, 1934). 
to be fastened on anything which can be identified as belonging to that category. There are some advantages in this. The phenomenal growth of group insurance has been followed by an equally phenomenal flood of litigation concerning it. The number of cases involving it decided in the last two years probably exceeds the entire number ever decided theretofore. A great deal of this litigation presents no new insurance problems, but merely timeworn questions which have been answered over and over again. The problems happen to arise in connection with group insurance, but they are not peculiar to it. Courts can dispose of these matters with ease and dispatch by applying existing insurance rules. Group life insurance is, and should be, commonly combined with disability insurance. The question of what constitutes total and permanent disability has arisen in a great number of group insurance cases, ${ }^{8}$ but it is an old, familiar question to which the courts merely repeat their familiar, if somewhat diverse, answers. Group insurance cases, drawn chiefly from the reports of the past two years, presenting other problems not peculiar to this type of insurance have been collected in an appendix to this article.

The general rules governing insurance, then, enable courts to dispose of much litigation concerning group insurance but presenting no special problems. Moreover, these general rules are useful in the solution of difficulties which are peculiar to group insurance. For example, a master or group policy issued to the employer provided that the insurance would terminate if the employer failed to remit the premiums to the insurance company, but the certificate issued the individual employee specified that the insurance would end at the close of the period for which premiums were paid by the employee to the employer, or deducted from the employee's wages. The court invoked the familiar insurance rule that the contract is to be construed most strongly against the insurer and most favorably to the insured, and took the position that therefore the employee could recover on the policy if the employer had deducted from the employee's wages premiums to cover the period including the date of the employee's disability, even though there was no evidence that the employer remitted the premiums to the insurance company. ${ }^{10}$

Something is gained, therefore, by the fact that group insurance has at hand a body of law developed and ready to be applied to it. But there is danger in this. Here is a new device, capable of great usefulness. The danger lies in thrusting the new device into an old category called "insurance" and subjecting it out of hand to

${ }^{8}$ Cassens v. Met. L. I. Co., I54 So. 522 (Fla. I934); Met. L. I. Co. v. Myers, I6r Va. 822, I72 S. E. 279 (1934); Kane v. Met. L. I. Co., 73 S. W. (2d) 826 (Mo. App., I934); Equit. L. A. Soc. v. Powers. 254 Ky. 770, 72 S. W. (2d) 469 (1934); Equit. L. A. Soc. v. Wiggins, x55 So. 327 (Fla. 1934); Holmes v. Met. I. I. Co. 187 Ark. 388, 6o S. W. (2d) 557 (I933); Met. L. I. Co. v. Tessier, 70 S. W. (2d) 209 (Tex. Civ. App. 1934); Cato v. Aetna L. I. Co., I64 Ga. 392, 38 S. E. 787 (1927). In Met. L. I. Co. v. Foster 67 F. (2d) $26_{4}$ (C. C. A. 5 th, I933) the court distinguishes between total andi permanent disability features in life policies, and policies providing bealth and accident insurance only. A lesser degree of disability may be deemed total and permanent under the latter policies.

${ }^{\circ}$ See p. 9r, infra.

${ }^{10}$ Mo. State L. I. Co. v. Compton, 73 S. W. (2d)', x079 (Tex. Civ. App. 1934). The court further says that since the employee earned wages from which the employer could have deducted the premiums, the insurance is in effect although the premiums were not in fact deducted. 
all the law gathered about the category. The judicial habit of putting a transaction into a category, and then subjecting it to the law of the category, has drawbacks at best. When the form of transaction is of a new type, widely used and susceptible of still greater use, the category to which it belongs should be subordinate to the inherent nature of the device itself in determining the law which shall govern it. If group insurance had been called "skeepjix," or some other name equally remote from the name of any known thing hitherto existing, perhaps attention would have been directed to its own nature, and perhaps more consideration would have been given to making the law fit and develop the newly created device. Group insurance, in short, should be regarded as sui generis, and in dealing with its peculiar problems the law should be concerned first and foremost with developing this social agency to its maximum usefulness, and insuring justice in its operation. It should not be clad in the straitjacket of legal rules made before it existed. It is from this viewpoint that the legal problems peculiar to group insurance will be treated.

\section{The Group}

As previously stated, the dominant characteristic of this form of insurance is that it covers by a single policy the individuals of a preëxisting group. It is this fact which makes possible the advantages which have promoted the swift growth of this device. Commonly the insurance is issued without medical examination of the individuals, since in the group there is usually an average health. A single policy being issued to be held for the group, the number of agents' commissions may be reduced to one, and clerical expense can be minimized.

Regulation concerning the insured group is largely regulation imposed by the association of companies writing group insurance, to which practically all such companies belong, ${ }^{11}$ or by statute. ${ }^{12}$ Some statutes specify the groups on which insurance may be written, make certain regulations regarding the insurance, and then restrict insurance on groups to the insurance expressly authorized in the statute. ${ }^{13}$ The wisdom of such a restriction is doubtful. Group insurance is itself recently graduated from the class of experiments, and its success demonstrates the value of experimenting. Further development ought not to be foreclosed. Suppose some company desires to insure the citizens of a certain town in mass, provided a given percentage of the citizens enter the scheme. Who is qualified to say that the venture would be of so much harm and so little value that people who want to make it ought to be forbidden to do so? Such an attitude would have prevented group insurance in the first place. It may in the future prevent wide expansion of the social usefulness of the device.

Groups authorized under the statutes of New York to be insured include em-

${ }^{21}$ The rules of this association are to be found in the office of the North Carolina Insurance Commissioner.

${ }^{13} \mathrm{New}$ York enacted the first statute regulating group insurance. Similar statutes more or less copied from this one appear in some twenty states. Note (I934) I2 N. C. L. REv. I66.

${ }^{23}$ N. Y. Cons. Laws (Cahill, I930) c. 30, §rorb (6); N. C. Code ANN. (Michie, I93I) $\$ 6466$ (b) (e). 
ployees of a single employer or his or its affiliates or subsidiaries, ${ }^{14}$ the units of the national guard or naval militia of any state, units of the state police, labor unions, borrowers from one financial institution, ${ }^{15}$ instalment purchasers from one vendor, and corporations or associations of veterans. Policies have been written on the members of clubs and associations, such as the Pilots, Masters and Mates Association of Inland Rivers. ${ }^{16}$

Besides employees of ordinary employers, group insurance is sometimes written on employees of political subdivisions, such as cities, ${ }^{17}$ or a state. ${ }^{18}$ The writer is informed by the representative of one insurance company that it has group policies on the employees of no less than thirty-two universities and colleges. On the question whether municipalities and other subordinate governmental units may enter such contracts for their officers and employees in the absence of a specific grant of authority to do so, the tendency is to support the power where the body for which such power is claimed has authority to fix salaries. ${ }^{10}$

In the past it was a common practice to issue group policies to associations of employees of an employer instead of to the employer direct. The practice is now

${ }^{14}$ Cases involving policies covering affiliates or subsidiaries are Powcll v. Equit. L. A. Soc., I73 S. C. 50, I74 S. E. 649 (I934); Bowen v. Met. L. I. Co., 67 S. W. (2d) I64 (Tenn. App. 1933).

${ }^{15} \mathrm{An}$ interesting policy of this sort was passed upon in Greer v. Aetna L. I. Co., 225 Ala. I2x, 142 So. 393 (1932). An insurance company having a loan department submitted to the state superintendent of insurance for approval a form of insurance including a master policy to be issued to the loan department, and a certificate to be issued to each borrower on mortgage security who was between twenty-ninc and fifty-nine years old and who cared to take the insurance. The premiums were $\$$ r.25 per month per thousand dollars of insurance regardless of the age of the borrower, the amount of insurance being the same as the loan and being reduced as the loan was reduced. In case of death the insurance went to pay the loan. The contract was held valid and not within the power of the superintendent to prohibit.

${ }^{28}$ This policy was before the court in Rowland v. Mo. State L. I. Co., 48 S. W., (2d) 3 I (Mo. App. 1932).

${ }^{17}$ Amer. Nat. I. Co. v. Westerfield, 73 S. W. (2d) I55 (Ark. 1934), and Davis v. Mct. L. I. Co., 16I Tenn. 655,32 S. W. (2d) ro34 (1930), both involved policies on police and fire departments.

${ }^{18}$ In All States L. 1. Co. v. Tillman, 146 So. 393 (Ala. 1933), the policy covered employecs of the state of Alabama.

${ }^{10}$ Nohl. v. Bd. of Education of Albuquerque, 27 N. M. 232, I99 Pac. 373 (1921) (school teachers); State $e x$ rel. Thompson v. Memphis, 147 Tenn. 658, 25 I S. W. 46, annotated, 27 A. L. R. 1257 (1923), approved in Ferrell v. Doak, I52 Tenn. 88, 91, 275 S. W. 29, 30 (1924) (municipal employecs). Contra: People ex rel. Terbush and Powell v. Dibble, 189 N. Y. Supp. 29 (Sup. Ct. 1921), affirmed by the Court of Appeals without passing on the power of the city to take the insurance, 23I N. Y. 593,132 N. E. 90I (I92I). The Court of Appeals took such particular pains to leave that question open as to suggest dis. approval or doubt of the decision below on the point. The premium expense is in effect a small advance in pay, from which it would seem to follow that where there are prohibitions on increasing salarics of officers during their terms, group insurance could not be written on them at public expense. See Bowers v. Albuquerque, 27 N. M. 29I, 200 Pac. 42I (I92I). The analogy between this provision for public employees and pension systems is apparent. On the latter see State v. Hauge, 37 N. D. 583,164 N. W. 289 (19r7); and generally, Wilgus, Constitutionality of Teachers Pension Legislation (1913) II Mrch. L. Rev. 451, I2 id. 27, 105. See also Lancaster v. Toronto, 38 Ont. L. R. 374, 34 D. L. R. 714 (1917), where a city took insurance on residents enlisting in the Canadian army, but the decision went off on the ground of deceased's non-residence; Mitchell v. Toronto, 50 Ont. L. R. 585, 64 D. L. R. 569 (1922). Cf. City of Red Wing v. Eichinger, 163 Minn. ${ }^{54}, 203$ N. W. 622 (1925), sustaining a city in taking' compensation insurance even when not compelled to do so. Such insurance might, of course, be directly for the benefit of the city in saving it from liability for injuries for which it was legally responsible. But so far as it covered non-negligent injuries it would be analogous to group life insurance, and the court relied on both types of authority. 
contrary to rule II of the association of group insurers. ${ }^{20}$ Statutory definitions of group insurance provide for the issue of the policy to the employer. ${ }^{21}$

Some statutes require that the policy cover not less than fifty employees; and that where the premium is to be paid by the employer and employees jointly and the benefits of the policy are offered to all eligible employees, not less than 75 per cent of the employees may be insured. ${ }^{22}$ These and other provisions are designed to procure an average group and prevent the insurance from being taken only by the diseased and other bad risks. Restrictions on the nature of the group, calculated to prevent groups from being formed principally for the purpose of taking the insurance, are likewise justifiable, where the insurance is to be issued without medical examination. Otherwise the unfit would join the group in order to secure the insurance.

\section{Forms of Group Insurance ${ }^{23}$}

The common form of group life policy is a policy for one year, but renewable from year to year. Under the earlier policies the employers usually paid the entire premium, but in recent years the tendency has been toward policies under the terms of which the employees contribute a portion of the premiums. ${ }^{24}$ Hitherto life policies commonly contained provisions for payments in case of total and permanent disability. The highly valuable effect of such provisions on the life insurance portion of the policy will be discussed later.

Although this article is concerned primarily with group life insurance, it is worth noting that group health and accident insurance, and group pension insurance is likewise written. The possibilities for bringing security in old age to wage earners under the latter form of group insurance make it a significant social development. ${ }^{25}$

\section{When the Insurance Begins}

Policies usually provide that the insurance shall not take effect as to a given employee until he has been in the service of the employer a specified period of time. ${ }^{26}$ Such provisions have a legitimate purpose, since large numbers of employees leave after short periods of service, and it would be inconvenient to insure these transients for their short terms of employment, especially since they might later make claims for disability alleged to have been incurred during their brief employment. Further, these provisions prevent uninsurable persons from entering employment expecting shortly to become disabled or die. Recovery under the policy will not be permitted until the employee has served the specified period. ${ }^{27}$

${ }^{90}$ The same rule condemns issuing group policies to associations of employers covering their employees.

${ }^{21}$ Supra note I.

2 Supra note $\mathrm{r}$.

${ }^{3}$ Statutes require the filing of all forms of group policies with the Insurance Commissioner or similar officer, and his approval of the forms. N. C. CODE ANN. (Michie, I93I) $\$ 6466$ (b); N. Y. Cons. LAws (Cahill, 1930) c. 30, §ror-b.

${ }^{24}$ Nat. Industrial CONF. BOARd, op. cit. supra note $\mathrm{I}$, at I5.

¿ For a discussion see Woods, The Sociology of Life Insurance (1928) 125.

${ }^{20}$ The period varies from none at all to five years. Nat. Industrial Conf. BoARd, op. cit. supra note $I$, at 12 .

$\pi$ Where an employee was disabled before he had served the required time, he was denied recovery 
Other provisions may be inserted in the policy concerning the service of the employee as a condition to the effectiveness of the insurance. For example, by a rider attached to the original group policy extended insurance was offered salaried and supervisory employees with a condition that before the extended insurance was to be available the employee desiring it must work at full time and for full pay. Thus the problem was raised what constituted working at full time. ${ }^{28}$

\section{WHEN THE INSURANCE ENDS}

Group insurance commonly being written on a term basis, the group policy in its entirety of course ends when the term is up, if the policy is not renewed. ${ }^{20}$ Policies frequently provide for a grace period of thirty-one days for the payment of premiums, during which period the insurance is to remain in force, but this provision should not keep alive for thirty-one days policies never renewed. The provision seems designed to preserve for that period policies renewed and paid for before the end of the period. $^{30}$ In the majority of group insurance cases, however, the courts take the opposite view..$^{31}$

on the insurance, even though the employer kept him on the books and paid him wages the required time, and even though a certificate of insurance was furnished by the insurance company and delivered to the employee by the employer after the period had elapsed. The insurer did not know the facts when it furnished the certificate. Arment v. Met. L. I. Co., 8 N. J. Misc. 100, I49 Atl. 35 (1930). See also Carson v. Henrietta Mills, 204 N. C. 667,169 S. E. 277 (1933).

${ }^{23}$ The court held that there was sufficient evidence on this point to go to the jury when the employee, an assistant superintendent, was sick from the time the insurance became available, and did not return to his office, but did transact at his home the necessary business of his employer connected with the $\mathrm{cm}$ ployee's duties. Equit. L. A. S. v. Worthman (C. C. A. 7 th, 1933) 67 F. (2d) 721. For a case holding an employee to be not "actively at work" so as to be entitled to additional insurance, see Leach v. Met. L. I. Co. supra note I, rehearing denied 125 Kan. I29, 263 Pac. 784 (1928).

In Kowalski v. Aetna L. I. Co. 266 Mass. 255, 265 N. E. 476,63 A. L. R. 1030 (1929) the original group policy covered employees after three months service; the policy was renewed, but did not then cover an old employee who was for a time out of the employer's service; and the court said this employec was therefore not covered even after she had again been in service three months. No reason is given for this result.

Where the employer pays all the premiums, and the group policy requires the names of the employecs insured to be certified by the employer to the insurance company, failure to include an cmployec in the list certified or to pay premiums for him prevents the insurance from being effective as to him. Magec v. Equit. L. A. Soc., 62 N. D. 614, 244 N. W. 518 (1932).

But in All States L. I. Co. v. Tillman, supra note 18 , the insurance was held good where an employec left in February and his insurance card was marked cancelled; then he re-entercd the employer's scrvice in August, deductions for premiums were made from his wages, and he died in November. This was true although no new card was made out, no new certificate was issued, and the employer remitted no premiums for him to the company. The court correctly pointed out that the employee has no means of knowledge of the relations between his employer and the company.

One the question when a group policy as a whole goes into effect, see Rowland v. Mo. State L. 1. Co., 48 S. W. (2d) 31 (Mo. App. x932).

${ }^{2}$ Infra note 33 .

${ }^{\infty}$ See Davis v. Met. L. I. Co., supra note r7.

${ }^{31}$ See Rowland v. Mo. State L. I. Co., supra note 28; Deese v. Trav. I. Co., 204 N. C. 214, 167 S. E. 797 (1933). Where the issue is as to the expiration of the insurance on the particular employce, rather than the expiration of the whole group policy, it has been said that the employee is covered for thirty-one days beyond the period covered by his premiums. Conn. Gen. I. I. Co. v. Horner, 2I S. W. (2d) 45 (Tex. Civ. App. 1929). One court went so far as to maintain that the employee was covered for thirtyone days beyond the termination of her insurance. Powell v. Equit. L. A. S., supra note 4 4. 
When the premiums are wholly paid by the employer, the policy may be cancelled by him, ${ }^{32}$ or he may decide not to renew it. ${ }^{33}$ Even where the employee pays part of the premiums the policy may be cancelled by agreement between the employer and the insurance company. ${ }^{34}$ The company may reserve the right to refuse to renew the policy if the number of insured employees falls below a named percentage of the total..$^{35}$ Of course, a valid cancellation cuts off the employee's right to recover for a loss thereafter sustained. ${ }^{36}$

\section{EfFect of Termination of Employment}

Group policies almost always provide that any employee's insurance ends when his employment ends. The provision may be in the group policy, the certificate, or both. The language in which the clause is phrased varies somewhat with the policies written by the different companies. But wherever it may be contained or however it may be stated, group insurance contracts characteristically provide that the insurance on an individual ceases when he ceases to be a member of the group. Since the usual group is formed of employees of one employer, the usual provision is that the insurance terminates with termination of that employment. This clause has been the center of great quantities of litigation. There is no doubt of the validity of such a provision, and accordingly, where it is established that the employee's loss came after the termination of his employment, there can be no recovery. ${ }^{37}$ If it is uncertain whether the loss for which insurance is claimed came before or after the employment ended, the question is one of fact for the jury. ${ }^{38}$ Where the policy covers disability, and the injury or disease which eventually produces disability begins while the employee is in the service of the employer, but does not produce the disability until some time after the employment has terminated for another reason, there can be no recovery. ${ }^{39}$

\footnotetext{
$\approx$ Austin v. Met. L. I. Co., I42 So. 337 (La. App. I932).

$\approx$ Thompson v. Pac. Mills, I4I S. C. 303 , I39 S. E. 619 (1927). The certificate to the employee stated that the taking of the policy did not establish a precedent to continue it.

is See Davis v. Met. L. I. Co., supra note 17. The cancelled insurance, however, was regarded by other group insurance, under which the beneficiary recovered.

${ }^{2}$ See Whitmire v. Prov. L. \& Acc. I. Co., 205 N. C. IOI, I70 S. E. II8 (I933). Here the employee sought to recover for fraudulent issue and cancellation of the policy on the ground that he had been told that the policy could not be cancelled so long as he remained an employee. Judgment for the employec was reversed, however, because the employee, when notified of the cancellation, took no action and accepted his pay without the premium deduction.

${ }^{2}$ Dean v. Met. L. I. Co., 205 N. C. 848 , I72 S. E. 403 (I934); Aetna L. I. Co. v. Gullett, 253 Ky. 544,69 S. W. (2d) 1068 ( 1934 ).

${ }^{5}$ Equit. L. A. Soc. v. Garrett, 25 Ala. App. 446, 148 So. 338 (1933); Conn. Gen. L. I. Co. v. Horner, supra note $3 \mathrm{I}$; Boozer v. Equit. L. A. Soc., 206 N. C. 848, I75 S. E. I75 (I934); see Morgan v. Trav. I. Co., I72 S. C. 404, 174 S. E. 235 (1934). The same result follows where there is no evidence that the employee's loss occurred before his employment ended. Equit. L. A. Soc. v. Arrowood, 253 Ky. 456, 69 S. W. (2d) 984 (r934). Conversely, where a loss is sustained, subsequent termination of employment does not prevent recovery. Turley v. John Hancock Mut. L. I. Co., 3I5 Pa. 245, I73 Atl. 163 (I934); Prud. I. Co. v. Cox, 254 Ky. 98, 7I S. W. (2d) 3I (r934).

${ }^{35}$ Hurt v. Equit. L. A. Soc., 53 S. W. (2d) rror (Mo. App. 1932); Smith v. Equit. L. A. Soc., 205 N. C. 387 , I71 S. E. 346 (I933); Equit. L. A. Soc. v. Fannin, 245 Ky. 474, 53 S. W. (2d) 703 (1932).

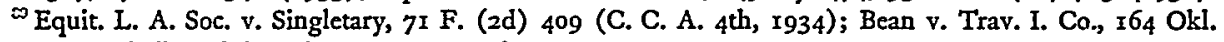
135,23 Pac. (2d) 216 (1933); Boozer v. Equit. L. A. Soc., supra note 37.
} 
It is not always easy to tell whether (or when) employment has ended. As might be expected, the question is for the jury if there are in evidence circumstances supporting the conclusion that employment has not ended, and other circumstances supporting the opposite result; ${ }^{40}$ and the jury is pretty sure to bring in a verdict against the insurance company. The company is frequently successful, however, in its contention that under the evidence employment is so clearly terminated that there is no question for the jury. ${ }^{41}$ Going out on strike has been held to be a termination of employment. ${ }^{42}$ However, in view of the difference between striking and quitting, ${ }^{43}$ a difference which may be invoked against the worker, ${ }^{44}$ a strike would more properly be treated as a temporary lay-off, especially where the strikers eventually are taken back.

A policy provision that ten days unexplained absence will be taken to mean that the employee has left his employment does not apply where the employee is laid off. ${ }^{45}$ Failure to secure written permission required by the policy for absence in excess of two weeks, does not terminate employment where request for permission is prevented by the nature of the sickness which caused the absence. ${ }^{40}$

The clause making group life insurance end when employment ends presents a difficulty. Suppose an employee becomes sick, leaves his employment, and dies of the sickness. If the clause is literally applied, his insurance ends when his employment ceases, and therefore his beneficiaries go unpaid. An employee's life insurance would be good for nothing unless he dropped dead on the job. An easy first among bad decisions in the field of group insurance is taken by Pegues $v$. Equitable Life. Assurance Society. ${ }^{47}$ The admitted facts were that the employee became ill while in employment from a disease, lead poisoning, resulting from the employment, left

${ }^{\infty}$ Cogsdill v. Met. L. I. Co., 158 S. C. 37 I, 155 S. E. 747 (I930); Deese v. Trav. I. Co., supra note 31 ; Trav. I. Co. v. Fox, I55 Md. 210, I4I Atl. 547 (I928); Joiner v. Met. L. I. Co., 40 Ga. App. 740, 151 S. E. 540 (1930); Aetna L. I. Co. v. Daniel, 25 I Ky. 760, 65 S. W. (2d) 1025 (r933); see Trav. I. Co. v. Tuck, 46 Ga. App. 533, r68 S. E. 81 (1933); Smith v. Aetna L. I. Co., 198 N. C. 578, I52 S. E. 688 (1930).

4 Beecey v. Trav. I. Co., 267 Mass. 135, I66 N. E. 57 I (I929); Bradley v. Prud. I. Co., 70 F. (2d) 988 (C. C. A. 9th, I934); Aetna L. I. Co. v. Lembright, 32 Ohio App. 10, 166 N. E. 586 (1928); Kowalski v. Aetna L. I. Co., supra note 28; Met. L. I. Co. v. Hawkins, 156 Va. 720, 158 S. E. 877 (193I); Aetna L. I. Co. v. Carroll, 188 Ark. 154, 65 S. W. (2d) 25 (I933); see Thull v. Equit. L. A. Soc. 40 Ohio App. 486, I78 N. E. 850 (I93I); Douglas v. Met. L. I. Co., 297 S. W. 87 (Mo. App. 1927); Wheeler v. Monsanto Chem. Works, 263 S. W. 881 (Mo. App. 1924); Peyton v. Met. L. I. Co., 148 So. 721 (La. App. 1933). For a holding that there was enough evidence to justify a finding by the jury that the insurance company had waived a policy provision excluding employees who ceased to work at full time for full wages, see Amer. Nat. I. Co. v. Chastain, x88 Ark. 466, 65 S. W. (2d) 899 (1933).

${ }^{13}$ Roehrig v. Mo. State L. I. Co., 25 I Ill. App. 434 (r929); Chrosniak v. Met. L. I. Co., I2I Misc. 453,201 N. Y. Supp. $21 \mathrm{X}$ (1923).

${ }^{4}$ Simpson, Constitutional Limitations on Compulsory Industrial Arbitration (1925) 38 HARv. L. REv. 753 , at 783 .

"See Toledo, A. A. \& N. M. Ry. Co. v. Penn. Co., 54 Fed. 746 (C. C. N. D. Ohio 1893), $a f^{\prime} d$, Ex parte Lennon, 166 U. S. 548 ( 1897 ).

${ }^{25}$ Aetna I. I. Co. v. Castle, 252 Ky. 228,67 S. W. (2d) I7 (1934); Aetna L. I. Co. v. Gullett, supra note 36 .

${ }^{23}$ Carruth v. Aetna L. I. Co., 157 Ga. 608, 122 S. E. 226 (1924).

77 S. W. (2d) 750 (Mo. App. 1933). 
work because of the illness, was treated by the employer as no longer an employee, and died of the illness about a year later. The employment and hence the insurance was held ended before the death, and judgment on the pleadings was given the insurance company.

One way of avoiding such a shocking result is, of course, to consider the employment as not being ended. ${ }^{48}$ Some policies make provisions concerning employees temporarily disabled, laid off, or on leave of absence; for example, a provision that the employer may elect to treat such employees as still in employment. Under such a provision, if the employer fails to make the election, the insurance ends. ${ }^{49}$ The circumstances may make it doubtful whether the employer elected to treat the employee as still in his service, in which case the issue is for the jury. ${ }^{50}$ Some policies provide that insurance ends when employment ends, except where the employee is disabled, in which case the insurance remains in force during the disability for three months, and thereafter during the disability and the continuance of the policy, until the employer notifies the insurance company to terminate the insurance of the employee. Where the employment of a wholly disabled employee ceased July $\mathrm{r}$, his insurance was cancelled September I2, and he died November 28, his insurance was held no longer in force under the above provision. ${ }^{51}$

The objection to such policy provisions as the above is that the insurance of an employee injured or taken sick on the job, and remaining sick or injured until he dies, is made to depend on the grace of the employer. This result is less objectionable where the premiums are wholly paid by the employer than where the employee has paid part of the cost of the insurance. ${ }^{52}$ But even where the premiums are furnished by the employer the employee may have paid for the insurance by taking it into account as part of his compensation, and furthermore, he may have refrained from securing other insurance by reason of reliance on the group coverage.

Greater justice to employees taken sick or injured while at work is accomplished

${ }^{4}$ See Aetna L. I. Co. v. Castle, stupra note 45; Thompson v. Pac. Mills, supra note 33; Prud. I. Co. v. Sweet, 253 Ky. 643, 69 S. W. (2d) 748 (1934); Prov. L. \& Acc. I. Co. v. Broome, 66 S. W. (2d) 104I (Tenn. App. 1933).

${ }^{19}$ Equit. L. A. Soc. v. Larocco, 68 F. (2d) $45 x$ (C. C. A. 3rd, I933), goes so far as to hold that where the employee is covered by two policies containing this provision, the employer referring to one policy may recognize the employee as still in employment, but that this recognition will not save the other policy. This seems peculiar. If the employee is once recognized as still being such, both policies should be still in force. The court rejects this argument.

If the employer makes a general election to recognize laid off employees as employees for a period of six months, an employee laid off for a longer period is not covered. Colter v. Trav. I. Co., 270 Mass. 424,170 N. E. 407 (I930).

${ }^{20}$ Porter v. Equit. L. A. Soc., 7I S. W. (2d) 766 (Mo. App. I934); Equit. L. A. Soc. v. Greene, 227 Ky. 43r, I3 S. W. (2d) 279 (1929); Powell v. Equit. L. A. Soc., stupra note I4; see Equit. L. A. Soc. v. McDanicl, $223 \mathrm{Ky}$. 505, 3 S. W. (2d) 1093 (r928).

"a Baker v. Trav. I. Co., 202 N. C. 432,163 S. E. IIo (I932). Notice by the employer to the company to terminate the insurance is a matter of defense, and need not be negatived by the employee. Trav. I. Co. v. Conine, 37 Ga. App. 500, 140 S. E. 784 (1927).

No distinction is preserved in this article between decisions involving insurance paid for by the employer and that paid for in part by the employee, for the reason that in a large number of cases it is not stated which kind of policy was before the court. 
by combining group life with group disability insurance. If the employee becomes sick or injured and as a consequence totally and permanently disabled, many policies provide that he shall be entitled to the amount of the insurance in specified periodic payments. If he dies, the unpaid instalments go to his beneficiaries. ${ }^{63}$ Under this form of insurance it has been held that termination of employment ends the insurance and the liability of the company for death benefits; ${ }^{54}$ but the obvious course open to the beneficiary is to sue the company on the disability provision, since on the termination of the employment of an employee already, disabled the disability insurance is due, and there is no further occasion for keeping the policy in force as to it. ${ }^{55}$ Some policies including disability insurance make the matter conclusive by providing that the insurance ceases when employment ceases except when the employee is then totally and permanently disabled. ${ }^{56}$ An additional difficulty is presented by policies which provide that an employee must be incapacitated for six months before he will be deemed totally and permanently disabled so as to recover disability payments. When an employee becomes incapacitated, but before six months elapse the insurance is ended as to this employee, it has been held that he is not disabled before the expiration of the insurance, because disability under the policy means disability for six months. ${ }^{57}$ While this is true if the provision be literally applied, the upshot is that for the final six months of the insurance the company takes no disability risk, since any disability sustained within six months of the end of the insurance could not ripen into the disability covered by the policy. A more equitable construction, therefore, would make the insurance payable at the end of six months when the disability began before the insurance ended, even though within six months of the disability the policy terminated. ${ }^{58}$ Certainly the policy should not be held terminated by termination of employment within the six months, because, if the disability must last six months before it is covered by the policy and if meanwhile the cessation of employment ends the policy, the company would never be liable on the disability insurance. ${ }^{59}$

Some policies provide that upon disability of an employee no premiums need be

${ }^{6}$ Rule ${ }^{3} 3$ of the association of companies writing group insurance provides that where insurance becomes effective after Oct. I, I932, policies should contain no disability clause providing cither: (a) for any payment during the lifetime of the employee, or (b) for waiver of premiums on a disabled employee for a period longer than the period he has been insured, or longer than one year in any event, or (c) for any payment if death occurs after the lapse of the group policy. However, any company may by notice escape this rule.

Steffen v. Equit. I. A. Soc. 64 S. W. (2d) 302 (Mo. App. I933).

${ }^{\star}$ See Horn's Adm'r v. Prud. I. Co., 252 Ky. I37, 65 S. W. (2d) I017 (1933); Smithart v. John Hancock Mut. L. I. Co., 7I S. W. (2d) ro59 (Tenn. I934).

${ }^{\infty}$ Trav. I. Co. v. Sanders, 47 Ga. App. 327, 170 S. E. 387 (1933) (group accident insurance).

${ }^{\pi}$ Aetna L. I. Co. v. Gullett, stupra note 36; Kingsland v. Mo. State L. I. Co., 66 S. W. (2d) 959 (Mo. App. I933).

${ }^{*}$ A good contrast is furnished by policies whereunder, as above pointed out, the company poclects premiums for six months period during which it cannot possibly be liable for disability claims, and those policies discussed in the next paragraph of the text wherein all premiums are waived upon disability.

${ }^{\infty}$ See Mo. State L. I. Co. v. Compton, 73 S. W. (2d) 1079 (Tex. Civ. App. 1934). 
paid for his insurance. ${ }^{60}$ This provision makes the insurance vastly more advantageous, since disabled workmen are likely to find it difficult to raise money to pay premiums. $^{01}$

It is usually held that the insured employee is not entitled to notice of the termination of his insurance, ${ }^{62}$ although there is authority to the contrary, ${ }^{63}$ and one court went so far as to indicate that even the beneficiary is entitled to notice. ${ }^{64}$

Bearing in mind the point already made that the law relative to group insurance should be developed in such fashion as to further the usefulness of the device and to secure its just operation, the writer is of the opinion that group policies should by statute be required to supplement their provision that the insurance ceases when employment ends with provisions excepting temporary lay-offs and leaves of absence, and not making the exception dependent on any election of the employer. The policies should further be required to provide that when an employee becomes sick or injured while employed, and leaves work for that reason, he shall continue to be insured during the continuance of his disability, without further payment of premiums. The policy might make this coverage during disability conditional upon giving notice to the insurance company within some specified time after the disability, in order to prevent employees or their beneficiaries appearing long after employment has ceased with claims for disabilities falsely said to have been sustained during employment, or claims for death of employees falsely said to have become sick during employment and remained sick until death. This provision might be supplemented by legislation making the employee's failure to give the notice within the required time forfeit the insurance. The policies should be required to provide, however, that an employee failing to appear on the job shall be given special notice of his obligation to give notice of his disability within the specified time, or be freed of the obligation. Requiring the employee to give notice of disability by a provision in

${ }^{\infty} \mathrm{A}$ policy provided that premiums should be waived on receipt by the company of proof of total and permanent disability. An employee became disabled, but sent the company no proof, and died some time after the period for which his premiums had been paid. It was held that the policy was nevertheless in force. The disability, rather than the proof, says the court, is the real condition precedent to the waiver of premiums. Home L. I. Co. v. Keys, 62 S. W. (2d) 950 (Ark. I933). Contra: Aetna L. I. Co. v. Allen, I74 S. E. 724 (Ga. App. 1934). In Smithart v. John Hancock Mut. L. I. Co., supra note 55, the policy covered disability, and also provided for a waiver of premiums upon receipt of proof of disability. Where proof was not furnished until some months after the disability, the insurance meanwhile having expired when the employer went out of business, the court held the insurance effective, since the loss occurs when the disability arises, and after the loss occurs the policy is payable and need no longer be kept in force.

"a See note 53 for a limitation on such a provision in future policies.

${ }^{\infty}$ Beecey v. Trav. I. Co., supra note $4 \mathrm{I}$; Thull v. Equit. L. A. Soc., supra note 4I; see Magee v. Equit. L. A. Soc., stupra note 28 . Nor is the employee entitled to notice of termination of his employment which terminates his insurance. Colter v. Trav. I. Co., supra note 49; Aetna L. I. Co. v. Lembright, supra note 41 ; Kowalski v. Aetna L. I. Co., stupra note 28.

${ }^{6}$ See Deese v. Trav. I. Co., supra note 3I. In Grossman v. London G. \& A. Co., I24 Mis. 520, 208 N. Y. Supp. 582 (1925), a statute requiring a provision in the policy for notice of cancellation to the insured was held to make ineffective a policy provision for cancellation on notice to the club holding the master policy, and to require notice to the individual member. No reason is apparent why the result should be any different where the group is formed of employees instead of club members.

"See Thompson v, Pacific Mills, stipra note 33 . 
the employee's certificate would not work as well as actual notice to the employee, for workers commonly become confused by the more or less technical provisions of their certificates.

The certificates given employees commonly provide, and in some jurisdictions by statute must provide, ${ }^{65}$ that on termination of employment ${ }^{60}$ the employee is entitled without evidence of insurability, upon application made to the company within thirty-one days after the termination, to a policy of other life insurance in an amount equal to his group insurance. The premium is to be determined by his then attained age. This latter feature is objectionable. An employee may spend most of his life with an employer who carries group insurance; then the employee may find himself out of work at an age at which the price of other life insurance is prohibitive. The premiums to the employee for the other insurance when his employment terminates should depend on his age when he was first covered by the group policy. ${ }^{67}$

Of course the privilege, open for thirty-one days after termination of employment, of taking other insurance regardless of insurability (good health), does not mean that the employee is insured for thirty-one days even though he does not exercise the privilege. If he dies within that time not having taken other insurance the company cannot be held, ${ }^{68}$ nor can the beneficiary take out the other insurance thereafter. Life insurance can scarcely be taken on a person already dead. ${ }^{00}$

The conversion privilege is not a valid basis for a contention that the employee who becomes sick or disabled on the job is adequately protected although his group

$\approx$ N. Y. Cons. Laws (Cahill, 1930) c. 30, \$ror-b (4); N. C. Code ANN. (Michie, 1931) $\$ 6466$ (b) (d).

${ }^{\infty}$ The conversion privilege is available only when employment terminates. See Magee v. Equit. L. A. Soc., supra note 28 .

A few days before a group policy was to be cancelled, an agent of the insurance company solicited employees to take other insurance, telling them they were entitled regardless of insurability to take out other insurance in any amount. This was false; the policy contained the usual provision making the conversion privilege arise on termination of employment, not on termination of the group policy, and limiting the amount of other insurance obtainable regardless of insurability to the amount of the group insurance. An employee was in the last stages of tuberculosis. His appearance showed his condition. He had $\$ 1500$ of insurance under the group policy and took $\$ 5,000$ of other insurance. He signed a blank application for it which the agent later filled in, falscly stating that the employce was in good health. The agent attached a false medical certificate to the application. Within a few weeks the $\mathrm{cm}$ ployee was confined to bed, where he remained until he died. The beneficiary sued on the new insurance, not for $\$ 5,000$, but for $\$ \times 500$, and recovered. The court pointed out that on termination of his cmployment the employee would have been entitled regardless of his condition to that much of other insurance, and save for the representation of the agent that he was already entitled to the insurance, would doubtless have terminated his employment to obtain it. Equit. I. A. Soc. v. Case, 167 Ok1. II9, 28 Pac. (2d) 57 I (1933). The limitation of the conversion feature to termination of employment is of doubtful merit. It should cover any termination of the employee's insurance. Under the existing provision when a policy is about to be cancelled an employee can gain an advantage by quitting which he could not have by remaining in employment; a result opposite to that usually sought by the employer when he takes out group insurance.

${ }^{\circ}$ Of course any additional advantage given employees by the terms of a group policy must be paid for in its premiums, but this point will be discussed hereinafter.

${ }^{\infty}$ Aetna L. I. Co. v. Carroll, supra note 41; Duval v. Met. L. I. Co., 82 N. H. 543, 136 Atl. 400 (r927).

${ }^{\infty}$ Fearon v. Met. L. I. Co., 246 N. Y. Supp. 701, 138 Misc. 710 (1930). 
life insurance ceases. In the first place a sick employee may be too sick to think about taking this other insurance. In the second place, being disabled, he may not be able to pay the premiums.

It is commonly held, as above indicated, that on termination of his insurance by cancellation or termination of employment, the employee is not entitled to notice. This is an injustice out of proportion to the inconvenience and expense the giving of such notice would entail. The employee, if his attention is called to the fact that he is now uninsured, may want to exercise the conversion feature above mentioned if the insurance has terminated by reason of termination of employment; or he may want to buy insurance on his own account elsewhere if the group policy has been cancelled or allowed to expire. Statutes might well impose on insurance companies the obligation to give this notice through the medium of the employer, on pain of having the group insurance continue until the notice is given.

\section{What Constitutes the Contract?}

A great conflict exists as to what constitutes the contract of group insurance. Some statutes require policies to provide that the policy, the application of the employer, and the individual applications, if any, of the employees, shall constitute the entire contract. ${ }^{70}$ Under such statutes there remains room for difference of opinion as to whether the "policy" made part of the contract is the master policy held by the employer, or that policy plus the certificates issued the employees. It has been intimated that the master policy is meant. ${ }^{71}$ Apart from such statutes the courts and diverse policy provisions have united to contribute the following confusion in rules. The master policy and the certificates constitute one indivisible contract; therefore (a) they must be construed together; ${ }^{72}$ (b) the failure to set forth the master policy makes the petition demurrable; ${ }^{73}$ and (c) failure to prove its terms precludes recovery. ${ }^{74}$ The certificates and a pamphlet describing the terms of the insurance are the contract. ${ }^{75}$ Where the master policy is not by the terms of the certificate made a part of the latter, and the certificate is complete in itself, and the company has not shown that the group policy, if proved, would present any defense to the company, it is not error to fail to plead or prove the group policy. ${ }^{76}$ If the company fails in the lower court to object to the fact that an action is based on the certificate instead of the group policy, and the company itself sets forth the policy,

${ }^{\pi}$ N. C. Cone Anv. (Michie, I934) $\$ 6466$ (b) (b); see N. Y. Cons. Laws (Cahill, I930) c. 30, \$ror-b (2).

${ }^{71}$ See Seavers v. Met. L. I. Co., I32 Misc. 719, 230 N. Y. Supp. 366 (1928). In Austin v. Met. L. I. Co., supra note 32, it was held that the group or master policy, not the certificate, is the "policy" under the Louisiana statute requiring life insurance policies to contain the entire contract between the parties.

${ }^{T 2}$ Smithart v. John Hancock Mut. Li I. Co., supra note 55; Mo. State L. I. Co. v. Compton, supra note 59; Carruth v. Aetna L. I. Co., supra note 46.

$7^{3}$ Met. L. I. Co. v. Harrod, 46 Ga. App. 327, I66 S. E. 870 (1932).

7 Wann v. Met. L. I. Co., 4I S. W. (2d) 50 (Tex. I93I).

${ }^{7}$ See Turley v. John Hancock Mut. L. I. Co., supra note 37. This result was reached on the pleadings.

${ }^{\text {To }}$ Mo. State L. I. Co. v. Copas, 265 III. App. 478 (1932). 
the objection is waived. ${ }^{77}$ The company must produce the master policy if it relies on any of the provisions of that instrument; otherwise the court is left only the certificate from which to ascertain the terms of the insurance. ${ }^{78}$ Conversely, if the employee relies on any provision of the certificate, he should allege the provision, or sue on the certificate. ${ }^{79}$ The employee must sue on the policy, not the certificate, but since the certificate incorporates the policy by reference (this is usually the case) the effect of pleading the certificate is to plead the policy. ${ }^{80}$ Where the certificate provides that the group policy plus the employer's application is the entire contract, there may be no recovery without introducing the group policy or showing an excuse for failure to do so. ${ }^{81}$ Where the employee has no access to the group policy it need not be shown, ${ }^{82}$ nor is he bound by its terms. ${ }^{83}$ The certificate is no part of the contract. ${ }^{84}$ The certificate embodies a separate and additional contract with the employee. Therefore, although the master policy was applied for, issued, and delivered in New York by a New York insurance company to a New York corporation as employer, the delivery of the certificate to an employee in Texas and collection of premiums there subjects the contract to a Texas statute providing penalties for non-payment by the company of the insurance. ${ }^{85}$ The court relies on a statute making contracts of insurance payable to inhabitants of Texas by a company doing business in that state (the court said defendant was doing business in Texas) governable by its laws; but an Arkansas court arrived at the same result without the aid of such a statute. ${ }^{80}$ The rules of the employer in connection with the insurance are part of the contract. ${ }^{87}$ A book of rules issued by the employer in connection with the insurance is no part of the contract. ${ }^{88}$ The provisions of a rider on the group policy prevail over the

7 Aetna L. I. Co. v. Daniel, supra note 40; Equit. L. A. Soc. v. Merlock, 253 Ky. ז89, 69 S. W. (2d) 12 (1934); Equit. L. A. Soc. v. Branham, $250 \mathrm{Ky} .472,63$ S. W. (2d) 498 (1933); sec Smith v. Equit. L. A. Soc., supra note 38 .

${ }^{7}$ Prud. I. Co. v. Sweet, supra note 48.

To Kingsland v. Mo. State L. I. Co., supra note 57.

${ }^{50}$ Prov. L. \& Acc. I. Co. v. Nicholson, 157 Va. 345, 160 S. E. 5 (193I).

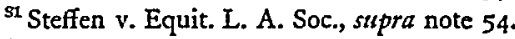

¿ See Sun L. A. Co. of Canada v. Coker, 187 Ark. 602, 6r S. W. (2d) 477 (1933).

${ }^{6}$ Mo. State L. I. Co. v. Johnson, I86 Ark. 5I9, 54 S. W. (2d) 407 (1932).

\& Thull v. Equit. L. A. Soc., stupra note $4 \mathrm{r}$; see Pool v. Protective I. I. Co., 155 So. 631 (Ala. App. 1934) cert. denied 155 So. 633 . In one case the holding that the certificate is no part of the contract worked to the advantage of the employee. It was held that when a former employec re-enters employment he does not have to obtain a new certificate, the latter being no part of the contract of insurance. All States L. I. Co. v. Tillman, stupra note 18. The policy contained the provision required by some statutes that the policy, the application of the employer, and the individual applications, if any, of the employees shall constitute the entire contract.

${ }^{\approx}$ Met. L. I. Co. v. Worton, 70 S. W. (2d) 216 (Tex. Civ. App. 1934).

${ }^{60}$ Met. L. I. Co. v. Harper, 70 S. W. (2d) 1042 (Ark. 1934). The court said, at ro45, "In this case the policy or certificate was delivered to appellee in Arkansas, and it was not effective until delivered." Note that the court referred to the certificate as the policy.

${ }^{57}$ See Rhodes v. Equit. L. A. Soc., 109 Ore. 586, 220 Pac. 736 (1923) (the certificate made the insurance subject to the employer's rules); Mattern v. Gas Companies', etc., Soc., I4I Misc. 510,253 N. Y. Supp. 124 (193I) (the policy was issued prior to the statute requiring the policy and application to contain the entire contract).

${ }^{88}$ See Equit. L. A. Soc. v. Hall, 253 Ky. 450, 69 S. W. (2d) 977 (1934). 
provisions of a certificate (although it does not appear in the report of the case that the date of the rider preceded the date of the certificate, and probably the reverse was true, and although it does not appear that the employee had notice of the rider).$^{89}$ A change in the policy restricting the risk is not binding on the employee unless he has notice of it. ${ }^{90}$

\section{Who Are Parties to the Contract?}

Courts have repeatedly said that the employer and the insurance company are the contracting parties, and the employee must take the contract made for his benefit as he finds it. ${ }^{91}$ One court said that the contracting parties are "primarily" the employer and the company, and that the rights of the employees are incidental; but in a later case the same court held that there is "a definite contractual relation between the insured employees and the insurer." In both cases the employees contributed part of the premiums. ${ }^{92}$ It is settled that the employee or his beneficiary may bring action on the group insurance in his own name. ${ }^{33}$ The employer need not be made a party. ${ }^{94}$ This result, explainable on the theory of third party beneficiary, is not inconsistent with the position that the employee is not a party to the contract; but it is further held that the employee is the insured within the rule that the contract is to be construed most favorably to the insured..$^{95}$ Moreover, under a statute requiring a policy provision that notice of cancellation be given the insured, the individuals of the insured group, a club, must be given the notice, not the club. ${ }^{96}$

The view that the employee is not a party to the contract takes little account of the nature of group insurance. It is true that the individual employees do not bargain with the company in person, but they do so through the medium of the employer. The object of the negotiating and of the insurance documents is to insure them, not the employer. Where they pay part of the premiums, it cannot be questioned that they furnish consideration. Even where the employer pays all the premiums, he usually does it in order to obtain some advantage from the employees, such as reduction in labor turnover, more loyalty and coöperation, ${ }^{97}$ etc. The insurance is part

${ }^{\text {E }}$ Equit. L. A. Soc. v. Sesco, 255 Ky. 298, 73 S. W. (2d) 47 (I934); Same v. Dennison, 255 Ky. 296, 73 S. W. (2d) 52 (I934); Same v. Patrick, 255 Ky. 290, 73 S. W. (2d) 49 (I934); see Same v. Branham, $250 \mathrm{Ky} \cdot 472,63 \mathrm{~S}$. W. (2d) 498 (1933).

Johnson v. Inter-Ocean Cas. Co., Ir2 W. Va. 396, I64 S. E. 4 II (I932).

$"$ Kingsland v. Mo. State L. I. Co., stupra note 57; Aetna L. I. Co. v. Gullett, supra note 36; Equit. L. A. Soc. v. Larocco, supra note 49 (involving both a policy paid for wholly by the employer, and one paid for partly by the employee); see Beecey v. Trav. I. Co., stupra note $4 \mathrm{I}$; but sce Mo. State L. I. Co. v. Johnson, supra note 83 .

${ }^{\circ}$ Compare Davis v. Met. L. I. Co., supra note 17, with Smithart v. John Hancock Mut. L. I. Co., supra note 55 .

${ }^{6}$ The great majority of the cases in this article involved actions so brought.

${ }^{4}$ Hamblin v. Equit. L. A. Soc., I24 Neb. 841, 248 N. W. 397 (1933).

to All States L. I. Co. v. Tillman, supra note $x 8$; Mandeville Mills v. Milam, 39 Ga. App. 768,148 S. E. 418 (1929).

${ }^{m}$ Grossman v. London G. \& A. Co., supra note 63 .

${ }^{n}$ Nat. Industriay Conf. Board, op. cit. supra note I, at Ix. The reasons given by employers for taking group policies are tabulated. See Thompson v. Pac. Mills, supra note 33; and note the employer's statement set out in Koch v. Aetna L. I. Co., 165 Wash., 329, 5 Pac. (2d) 313 (I93I). 
of that which the employee receives for his labor. Thus consideration is furnished in service to the employer, who passes the consideration on to the company in the form of money. Policies often contain an implied recognition of the fact that the insurance is given in return for long and regular service by making the amount of the insurance held by each individual employee depend on the length of his service. ${ }^{08}$ Furthermore, a provision making the employee's group insurance non-assignable has been supported on the ground that the chief motive of the employer in securing group insurance is to induce employees to remain in service, a motive which would be defeated if the policy were assignable.99

\section{The Position of the EMPLOYER}

Courts have taken great pains to determine whether the employer is the agent of the insurance company or not. Better results might have been achieved had they gone directly to the problem of determining whether, in view of the way group insurance is set up and operated, and of the relations and character of the parties, the employer should be charged with the performance of certain functions on behalf of the insurance company. If it is found that the employer should be held to act for the company in certain particulars, it is not objectionable to describe the result by saying the employer is the company's agent for those purposes. If it is determined that in other particulars the employer's acts should not be chargeable to the insurance company, it is equally unobjectionable to label this result by stating that the employer is not the company's agent for those other purposes. The harm comes in reversing the process. When courts first examine the question whether under the law the employer is an agent, find he is not, and then decide that therefore he is not to be charged with certain functions on behalf of the insurance company, the law does not serve group insurance, but group insurance the law.

Of course even those courts primarily concerned with tagging the employer as agent or no agent cannot make one tag suffice. It is impossible to determine that the employer is, or is not, the agent of the company for all purposes and under all policies. Group insurance may be written under a variety of arrangements. A case where the acts of the employer were held to bind the company is Porter v. Equitable Life Assurance Society. 100 Here the employer deducted premium payments from the employees' wages and sent them to the company; all applications and cancellations were handled by the employer's bookkeeper; a supply of blank individual applications and certificates, furnished by the company, was kept on hand by the employer, and filled in by the employer's office manager before delivery; the employer furnished the company a list of applicants each month, but wrote the certificates without waiting to hear from the company; all claims had to be made to the office manager, who then sent to the company for blanks to make proof of claim, the proofs being for-

\footnotetext{
${ }^{\infty}$ Such policies were involved in Aetna L. I. Co. v. Castle, supra note 45; Austin v. Mct. L. 1. Co., supra note 32; Dean v. Met. L. I. Co., supra note 36, and other cases cited in this article.

${ }^{90}$ Met. L. I. Co. v. Brown's Adm'r., 222 Ky. 21 I, 300 S. W. 599 (1927).

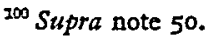


warded to the company; and checks in payment of claims were sent by the company to the office manager. The office manager directly supervised the group insurance, but the employer had a central office in which there was an insurance department conducted by a manager. All reports of employees insured and checks for premiums were forwarded by the office manager to the insurance department manager and by him to the company. Plaintiff was an employee who had a claim under the group insurance. An agent of the insurance company wrote plaintiff's attorney stating that all matters pertaining to claims were handled through the employer's insurance office, and that plaintiff employee's claim had been referred to the manager of the employer's insurance department. The court held on the above facts that the employer had authority to speak and act for the company in all matters concerning the employee's certificates and claim, and that letters of the office manager and manager of the insurance department concerning the employee's insurance and claim could be introduced as evidence against the insurance company.

The above case is presented in some detail in order to show how completely the administration of the insurance is sometimes left to the employer. To say under such circumstances that no acts of the employer are binding on the company would be nonsense.

The employer is commonly given the function of deducting premium payments from the wages of employees, and remitting the money to the company. The deduction by the employer is payment to the company, ${ }^{101}$ whether or not the employer remits to the company. ${ }^{102}$

A case arose in which it was doubtful whether an insured individual was an employee or not, but the court held that since the employer was authorized to receive and transmit applications of employees and issue certificates, it was the agent of the company in submitting the application and having the policy here involved issued; therefore its knowledge concerning the individual's standing as an employee was chargeable to the company. ${ }^{103}$ An opposite result was reached by a court which concluded that the employer was not an agent of the company, and that therefore the employer's knowledge of the age of an employee was not the knowledge of the company. ${ }^{104}$

${ }^{102}$ Deese v. Trav. I. Co., supra note $3 \mathrm{I}$.

${ }^{100}$ Mo. State L. I. Co. v. Compton, stupra note 59 (provision of certificate applied); but see Sun L. A. Co. of Canada v. Coker, supra note 82. In the Compton case the court said that the employee could recover if he had earned wages from which premiums could have been deducted, even though they were not.

In some instances the employer is paid a commission for collecting premiums from the employees, in which case it is clear he is an agent for that purpose. See Somog v. W. Va. \& Ky. Ins. A., Iro W. Va. 205 , 557 S. E. 400 (I93I). However, rule 9 of the association of companies writing groupt insurance provides that the employer shall not be paid in any way for services performed under the group policy.

${ }^{163}$ Equit. L. A. Soc. v. Florence, 47 Ga. App. 7II, I7I S. E. 3 I7 (1933). The court further held that an incontestable clause in this policy precluded the company's defense that deceased was not an employee. In Dees v. Nat. Cas. Co., 66 S. W. (2d) 603 (Tenn. App. I933), persons performing functions usually performed by the employer were said to be agents of the company.

${ }^{10}$ Equit. L. A. Soc. v. Hall, stupra note 88. The court said the relation of principal and agent existed between employer and employee, not between employee and company. 
The evil results which arise when courts lose sight of the nature of group insurance are illustrated by a case in which the paymaster of the employer was in charge of the group insurance of employees and handled disability claims of employees, yet notice to him of the disability of an employee was held not to be notice to a proper agent of the insurance company, since there was no evidence that the paymaster acted for the company rather than for the employer. ${ }^{105}$ The fact that the insurance company operated its business of insuring employees through the medium of the paymaster, and the fact that the employees naturally would go to the official of their employer having charge of the insurance, and that the insurance company should and apparently did expect them to do so, make this a clear case where the court should have held that the function of receiving notice of claims was a function of the employer in the normal operation of the policy.

An equally bad result was reached when the question arose whether an insurance company whose policy covered local employees could be served as a foreign corporation doing business in the state. The court held that the employer who dealt with the local employees was not an agent of the company, and that therefore the company was not doing business in the state. ${ }^{106}$ This outcome makes it necessary for an employee sold insurance in his own state to sue elsewhere before he can hold the company. Most employees would find their insurance of little value if they were obliged to go to some distant state to enforce it.

Where an employer discharged an employee, who was drowned within a week afterwards, evidence that the employer agreed to reinstate the employee and waive the termination of the insurance was excluded. ${ }^{107}$ The result is justifiable and could have been placed on the ground that an employer cannot reinstate terminated insurance without express authority from the company, but the court plunged into an extensive examination of the question whether the employer is an agent, and considered and rejected various bases for holding the employer to be the agent of the company. The court insisted that the employee looked to the employer as an employer, not as an agent of the company, and that the connection between the employer and employees is closer than that between the employer and the company. ${ }^{108}$ It is

${ }^{200}$ Ammons v. Equit. L. A. Soc., 205 N. C. 23 , I69 S. E. 807 (1933). The notice was oral, but the court said it was not required to be written. The employer may be an agent to handle all matters pertaining to premiums and claims. See Prud. I. Co. v. Sweet, stupra note 48.

${ }^{100}$ Conn. Gen. L. I. Co. v. Speer, 185 Ark. 615,48 S. W. (2d) 553 (1932). The case is repletc with bad reasoning. The court argues that since the company looked to the employer for premiums, it was immaterial that the employer collected part of them from the employees; further, that the company was not concerned with the number of employees making application. That the truth is precisely the opposite is recognized by many companies which require a certain percentage of the employees to take the insurance before the group policy will be issued or renewed. See Rule I9 of the association of companics writing group insurance. It is obvious, further, that if the employees do not take the insurance and pay part of the premiums the company cannot do this group business. The number of premiums the company receives depends on the number of employees who pay them.

${ }^{107}$ Duval v. Met. L. I. Co., supra note 68 . The case is relied upon, in other cases holding that the employer is not the agent of the company. See Leach v. Met. L. I. Co., stupra note 1.

${ }^{109}$ See also note 104. However, in Joiner v. Met. L. I. Co., supra note 40 , it was held that the employer is not the agent of the employee so as to make a declaration of the employer to the company after 
hard to see why this fact should prevent courts from holding that by the nature of group insurance the employer is called upon to perform certain functions, that the company contemplates that he will do so, and should be bound by his performance when he does so.

Some policies contain provisions giving the employer special rights or powers. A policy provided that disability payments might be made in a fixed number of instalments chosen by the employer from a table in the policy. Denial of liability by the company was held to waive the option to pay in instalments, hence the right to have the employer fix the amount. ${ }^{109}$. Another policy provided that the beneficiary could be changed subject to the employer's approval. Absence of such approval was held to be an objection which could be raised only by the employer. ${ }^{110}$ A provision requiring notice of sickness to the employer was said to be for his benefit and subject to waiver by him. ${ }^{111}$ Group insurance is usually considered a device whereby employers contribute security to their employees, but the device was used for the opposite purpose by one employer. The policy, the premiums for which were deducted from the wages of the employees, made the proceeds payable to the employer, who could keep the amount of any cash advances made the employee, or of "any promissory notes of the insured in favor of the employer," or of various other claims. ${ }^{112}$ It was held that the employer could not keep from the proceeds of the insurance the amount due on a note made before the employee entered his employer's service for an obligation not connected with the employment. ${ }^{113}$

It is established that the employer cannot be held liable in an action on the policy. The insurance company, not the employer, is the insurer. ${ }^{114}$ Neither may the employer be held liable in damages to the employee's beneficiary for failure to keep the insurance in force. ${ }^{115}$ This result is founded in part on the proposition, previously criticised herein, that the insurance is a gratuity, not part of the employee's compensation.

One case exists in which an employee, suing his employer for dismissal contrary to the terms of an employment contract, sought to include in his recovery damages for the loss of his rights under a group insurance policy. The court held that no damages could be recovered for this loss, since the insurance was issued subsequent

the employee's death that employment had previously been terminated binding against a claimant under the employee's policy.

${ }^{100}$ John Hancock Mut. L. I. Co. v. Cave, $240 \mathrm{Ky} .56,40 \mathrm{~S}$. W. (2d) I004 (I93I). See also Famblin v. Equit. L. A. Soc., supra note 94 .

${ }^{110}$ See Martinelli v. Cometti, I33 Misc. 8ro, 234 N. Y. Supp. 389 (1929).

in Carruth v. Aetna I. I. Co., supra note 46.

110 This perversion of the purpose of group insurance has been headed off by statute. See note I.

${ }^{113}$ Mandeville Mills v. Milan, supra note 95.

n' Carpenter v. Chic. \& E. I. R. Co., supra note 3; Wheeler v. Monsanto Chem. Wks. supra note 4I; Gallagher v. Simmons Hdwe. Co., 214 Mo. App. IrI, 258 S. W. 16 (1924); see Colter v. Trav. I. Co., stipra note 49; but see Aetna L. I. Co. v. Lembright, supra note $4 \mathrm{~T}$.

14 Kowalski v. Aetna L. I. Co., supra note 28 (premiums paid by the employer); Meyerson v. New Idea Hosiery Co., 217 Ala. 153, II5 So. 94 (I927) (premiums paid in part by employee); see Peyton v. Met. L. I. Co., supra note $4 \mathrm{I}$. 
to the employment contract and was not referred to in the contract. Only such damages may be recovered as arise naturally and in the usual course of things from the breach, and such as the parties contemplated when the contract was made as the probable result of its breach. ${ }^{116}$ It is submitted that the group insurance should under such circumstances be treated as a wage increase would be treated. It is something additional given in return for continued service.

\section{Vexatious Delay Statutes}

A number of group insurance cases have been concerned with the application of statutes which provide penalties and attorney's fees to be recovered by the claimant when an insurance company fails to pay a claim for insurance. ${ }^{117}$ This problem is not peculiar to group insurance; ${ }^{118}$ but the value of such statutes may be increased by the growth of insurance covering large groups of workers with small incomes. Such persons are in a poor position to stand the expense of litigation, and accordingly in connection with group insurance there is something to be gained by subjecting insurance companies to additional payment where they contest claims which turn out to be valid.

\section{COST OF IMPROVEMENTS}

During the course of this discussion a number of suggestions have been advanced for making group insurance operate more justly to the employees insured. Of course any new advantages given the insured employees must be paid for in the premiums. It may be argued that the mounting success of group insurance rests on its low price; that employers take out such insurance on behalf of their employees and pay all or a portion of the premiums because they desire to effect for the employees the economies of a form of insurance cheaper than individual employees could buy. It must be remembered, however, that the cheapness of group insurance is supposed to spring from economies produced by the nature of the device, such as the elimination of medical examinations, and the saving in agents' commissions and administration expense attendant on insuring many persons at once. If group insurance can be kept cheap only by being kept inferior, then its cheapness is deceptive. Shoddy goods can always be sold at cut rates. Insurance of bad quality can be sold at a low price. Group insurance would deserve no place as a new social device if it constituted nothing more than the bargain basement of insurance companies.

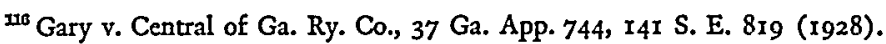

${ }^{117}$ Amer. Nat. I. Co. v. Westerfield, 73 S. W. (2d) 155 (Ark. I934); Met. L. I. Co. v. Harper, supra note 86; Mo. State L. I. Co. v. Brown, I88 Ark. 1136, 69 S. W. (2d) 1075 (1934); Mo. State L. I. Co, v. King, I86 Ark. 983, 57 S. W. (2d) 400 (r933); Sun L. Assur. Co. of Canada v. Coker, stupra note 82; Met. L. I. Co. v. Worton, stipra nota 85; Crowe v. Equit. L. A. Soc., 179 La. I44, 154 So. 52 (1934); Porter v. Equit. L. A. Soc., supra note 50.

${ }^{118}$ For a general discussion of this type of statute, see Note (1934) 48 HARv. L. REv. 3 I9. 


\section{APPENDIX}

The cases collected below indicate the recurrence in the field of group life and disability insurance of problems which had already been the subject of considerable litigation involving individual policies. Most of the decisions cited were reported during the past two years.

(I) Whether judgment will be given for disability instalments not yet due under policy when action is brought.

Kentucky courts award judgment for the future instalments to be paid when due under the terms of the group insurance, unless the disability meanwhile ends, retaining the case on the docket with the right in the defendant insurer at any time to show that disability has ended. Equit. L. A. Soc. v. Goble, 254 Ky. 6I4, 72 S. W. (2d) 35 (1934); Equit. L. A. Soc. v. Martin, 254 Ky. 747, 72 S. W. (2d) 446 (1934); Equit. L. A. S. v. Morgan, 254 Ky. 699,72 S. W. (2d) 46 (I934); Prud. I. Co. v. Hampton, 252 Ky. I 45. $65 \mathrm{~S}$. W. (2d) 980 (1933). In a Missouri caso judgment was given only for the yearly instalment due. Hardie v. Met. L. I. Co., 7 S. W. (2d) 746 (Mo. App. 1928). Where the insurer denies that the insurance is in force, the present value of future instalments may be recovered as damages for breach of contract. Met. I. I. Co. v. Gregory, 188 Ark. 516,67 S. W. (2d) 602 (1934). The same result was reached where the insurer denied liability. Sun L. A. Co. of Canada v. Coker, 187 Ark. 602, 6r S. W. (2d) 447 (1933). See Prud. I. Co. v. Faulkner, 68 F. (2d) 676 (C. C. A. 1oth, 1934).

(2) Time when proof disability must be furnished insurance company.

If the group insurance contract does not state any time within which proof must be submitted to the insurer, it has been held that there is no time limitation, not even the bounds of a reasonable time. Amer. Nat. I. Co. v. Chastain, 188 Ark. 466, 65 S. W. (2d) 899 (r933); see Amer. Nat. I. Co. v. Westerfield, 73 S. W. (2d) 155 (Ark. x934); Aetna L. I. Co. v. Wells, 254 Ky. 650, 72 S. W. (2d) 33 (1934). In Burton v. Met. L. I. Co., I77 Ga. 899, I73 S. E. 922 (x934) it was held that proof must be furnished the insurer within a reasonable time, but that there was still a case for the jury as to the reasonableness of the time when proof had not been furnished until almost six years had passed. Where the policy provided that disability payments would be made upon receipt of proof of disability before the expiration of one year from commencement, this was held to mean one year from the commencement of disability, not from the time of the accident which produced disability. Crowe v. Equit. L. A. Soc., I79 La. 444, 154 So. 52 (1934).

(3) Waiver of proof of disability or death.

Denial of liability is a waiver of proof of disability or death to the insured. Porter v. Equit. L. A. Soc., 7I S. W. (2d) 766 (Mo. App. I934); Trav. I. Co. v. Sanders, 47 Ga. App. 327, I7o S. E. 387 (1933); Cogsdill v. Met. L. I. Co., I58 S. C. 371 , I55 S. E. 747 (1930). Proof of continued disability is waived when the insured individual appears for examination before a doctor named by the insurer. Hardie v. Met. L. I. Co., supra paragraph ( $\mathrm{I}$ ).

(4) Waiver of premiums.

Refusal of premiums on the ground that the insurance has terminated excuses further payment of premiums. Mo. State L. I. Co. v. Compton, 73 S. W. (2d) x079 (Tex. Civ. App. 1934).

(5) Waiver of other policy provisions.

Prov. L. \& Acc. I. Co. v. Nicholson, 157 Va. 345, I60 S. E. 5 (1931); Hamblin v. Equit. L. A. Soc., 124 Neb. 841, 248 N. W. 397 (1933); Rowland v. Mo. State L. I. Co., 48 S. W. (2d) 31 (Mo. App. 1932).

(6) Time when payments by insurance company are to begin.

Some group policies provide that disability payments shall begin six months or some other stated period after proof of disability is received by the insurer. It was held that an action brought within six months was premature, even though the insurer had denied liability altogether. Hundley v. Met. L. I. Co., 205 N. C. 780, 172 S. E. 36I (1934). Contra: Sun L. A. Co. of Canada v. Coker, supra paragraph (I); and see Prud. I. Co. v. Faulkner, supra paragraph $(x)$, as amplified by the dissent. Where the policy provides that disability payments shall begin after approval of the proof of disability by the insurer, the company is entitled to make an investigation expeditiously and in good faith before it approves, and until then the payments are not due. Mo. State L. I. Co. v. King, I86 Ark. 983, 57 S. W. (2d) 400 (1933). 
(7) Whether injuries or death are produced by accident.

Smith v. Met. L. I. Co., 152 So. 369 (La. App. 1934); Prud. I. Co. v. Dudderer, 25I Ky. 627, 65 S. W. (2d) 745 (1933); Prud. I. Co. v. Downs, 251 Ky. 208, 64 S. W. (2d) 902 (1933); Prud. I. Co. v. Calvin, 227 Ala. 146, 148 So. 837 (1933).

(8) Effect of suicide on action for accidental death benefits.

Recovery was refused where the evidence showed suicide. Prud. I. Co. v. Tuggle's Addm'r, $254 \mathrm{Ky}$. $8 \mathrm{r}_{4}, 72 \mathrm{~S}$. W. (2d) 440 (r934).

(9) Effect of policy provisions requiring attendance by a physician as condition to recovering disability payments.

Where the policy provides that sick benefits shall not be paid unless the insured employee is attended by a physician during the time for which he claims benefits it is improper to allow recovery for periods during which there is no such attendance. Equit. L. A. Soc. v. Branham, 250 Ky. 472, 63 S. W. (2d) 498 (1933); Cf. Equit. L. A. Soc. v. Burns, 254 Ky. 487, 7x S. W. (2d) 1009 (1934).

(Io) Effect of usual limitation of total and permanent disability payments to disabilities sustained before reaching age sixty.

This clause is enforceable although the individual insured was to the knowledge of the insurance company beyond the age of sixty when he was included in the group insured. There is no waiver or estoppel to be asserted against the company on the ground that if it enforces the clause it has sold a useless policy, because the policy contains other insurance protection to the employee too old to have the disability protection. Hollis v. Trav. I. Co., 175 S. E. 33 (Ga. App. 1934); Pool v. Protective L. I. Co., I55 So. 63 (Ala. App. 1934) (cert. denied 155 So. 633); Ellis v. Sun L. A. Co. of Canada, 188 Ark. Ir67, 67 S. W. (2d) 740 (r934); Rogers v. Met. L. I. Co., 265 Mich. 202, 25I N. W. 312 (r933); MacLain v. Amer. Glanzstoff Corp. I66 Tenn. I, 57 S. W. (2d) 554 (1933).

(II) Operation of incontestable clause.

Some states by statute require group policies to provide that the policies shall be incontestable after twa years except for non-payment of premiums or violation of policy conditions relating to military or naval service in time of war. N. Y. Cons. Laws (Cahill, 1930), c. 30, §ror-b (1) N. C. Code ANN. (Michie, 1931) $\$ 6466$ (b) (a). An incontestable clause does not, however, prevent the insurance company from defending an action for disability benefits on the ground that these were not payable for disabilities sustained after the age of sixty. The clause does not enlarge the risk covered by the policy. Hollis $v$. Trav. I. Co. supra paragraph (10). See note 103 to text, stupra p. 87.

(I2) Designation and change of beneficiary.

Some group policies make the employer the beneficiary. The employer is then a trustce of the proceeds. See In re Hooper's Estate, 146 Misc. 15I, 26I N. Y. Supp. 585 (I932); Fid. \& Cas. Co. v. Ballard \& Ballard, x05 Ky. 253, 48 S. W. 1074 (1899); United Zinc Cos. v. Gen. Acc. A. Corp., I25 Mo. App. 4r, 102 S. W. 605 (1907). Statutory definitions in some states include a provision that the insurance be for the benefit of persons other than the employer. See note I to text, supra p. 70. Where the employee by the terms of the policy may choose the beneficiary, then in the absence of any policy restrictions, he may name any beneficiary he desires regardless of that person's insurable interest. Levas v. Met. L. I. Co., 175 Wash. I59, 26 Pac. (2d) 1032 (1933). The beneficiary was held sufficiently identificd in that case, and likewise in Aetna L. I. Co. v. Hartley, 4 F. Supp. 639 (D. Md. 1933). Where the policy required endorscment of change of beneficiary on the employee's certificate, the employee's application for a change was not effective until the endorsement, and that not being made until the employce died, the change was never effective, the old beneficiary's rights having vested on death of the insurcd employee. Met. L. I. Co. v. Lewis, 142 So. $72 x$ (La. App. 1932). A will not being in accord with procedure prescribed in the policy for change of beneficiary was held not to accomplish such change in Met. L. I. Co. v. Brown's Adm'r, 222 Ky. 21I, 300 S. W. 599 (1927); Seavers v. Met. L. I. Co., 132 Misc. 719, 230 N. X. Supp. 366 (I928). But in Martinelli v. Cometti, r $_{33}$ Misc. 810, 234 N. Y. Supp. 389 (1929), a will leaving part of the insurance proceeds to others than the beneficiary named was held to work a valid change of bencficiary to the extent of the amount left in the will, notwithstanding a policy provision that the beneficiary could be changed subject to the employer's approval. Here there was no such approval before the death of the employee, but the court said that lack of such approval is a matter which only the employer may raise. Contrary to Met. L. I. Co. v. Lewis, supra, is Johnston v. Kearns, 107 Cal. App. 557, 290 Pac. 640 (1930), holding that where the employee before his death does all in his power to change the beneficiary, the 
change will be effective, notwithstanding a policy provision that the change would take effect only on receipt of the request at the company's home office, and the fact the request was not received before the employee died. The company did not contest the change. Where the policy does not specify how the beneficiary is to be changed, any act indicating the employee's intention to make the change will suffice. Koch v. Aetna L. I. Co., I65 Wash. 329, 5 Pac. (2d) 313 (193I). In Rhodes v. Equit. L. A. Soc., rog Ore. 586, $220 \mathrm{Pac}$. 736 ( 1923 ) where the insurance was made subject to a rule of the employer that only dependents or persons related by blood or marriage to the employee could be made beneficiaries without securing the employer's consent, the designation of a divorced wife was held valid without such consent, in the absence of objection from the employer. In Enright v. Standard L. \& Acc. I. Co., 9x Mich. 238, 5I N. W. 928 (1892), it was held that a wife entitled to the insurance as a beneficiary can give up such rights and recover as administratrix.

(13) Whether policy must be in writing.

Oral contract enforced: Fid. \& Cas. Co. v. Ballard \& Ballard, ro5 Ky. 253; 48 S. W. 1074 (1899). Oral modification of written policy enforced: United Zinc Cos. v. Gen. Acc. Assur. Corp., supra paragraph I2; ibid., 1 44 Mo. App. 380 , 128 S. W. 836 (1910). Oral contract invalid by statute: see John Hancock Mut. L. I. Co. v. Ludwick, 45 Ga. App. 631, 165 S. E. 918 (I932).

(14) Attorney's lien on proceeds of policy.

Brookshire v. Met. L. I. Co., 56 S. W. (2d) 817 (Mo. App. 1933).

(I5) Various points of evidence and procedure.

Prov. L. \& Acc. I. Co. v. Broome, 66 S. W. (2d) ro4I (Tenn. App. 1933); Aetna L. I. Co. v. Daniel, $251 \mathrm{Ky} \cdot 760,65$ S. W. (2d) 1025 (1933); Bowen v. Met. L. I. Co., 67 S. W. (2d) I64 (Tenn. App. I933); Prud. I. Co. v. Calvin, stupra paragraph (7); Equit. L. A. S. v. Preston, 253 Ky. 459, 70 S. W. (2d) I8 (1934); Trav. I. Co. v. Fox, 155 Md. 210, r4I Atl. 547 (r928). 